\title{
Teachers' attitudes and the challenges they experience concerning individualized education program (IEP): A mixed method study
}

\author{
İshak Kozikoğlu* \\ Department of Educational Sciences, Van Yüzüncü Yıl University, Van, Turkey \\ ORCID: 0000-0003-3772-4179
}

\author{
Ezgi Nur Albayrak \\ Bahçeşehir College, Van, Turkey \\ ORCID: 0000-0003-3589-879X
}

Article history

Received:

01.10 .2020

Received in revised form: 31.05.2021

Accepted:

21.06.2021

Key words:

Individualized education program;

IEP;

Attitude;

Challenges;

Inclusive education;

Teachers
In this study, it was aimed to examine teachers' attitudes and challenges they experience concerning Individualized Education Program (IEP). Explanatory sequential design, one of the mixed methods, was used in this study. The study group of this study consists of 100 teachers working in the central districts of Van, Turkey within 2019-2020 academic year. In data collection, the scales of "Determining the Attitudes towards IEP Preparation Process", "Determining the Challenges Concerning IEP Preparation Process" and a semi-structured interview form were used. Findings demonstrated that teachers have positive views about the IEP process, and the implementation of IEP is useful and essential. Concerning the challenges they experience during the IEP process, the teachers think that they do not have sufficient information about the planning, implementation and assessment/evaluation processes of IEP, the school/classroom is physically inadequate, and the classes are crowded in the implementation of IEP. In addition, it was found that as the positive attitudes of the teachers towards IEP increased, the challenges they encountered during the IEP process decreased. Based on the results of this study, it can be suggested that teachers should receive in-service training, physical conditions should be improved, the class size should be reduced, and cooperation should be provided between the family, classroom teachers and guidance counselor in order to conduct IEP in a healthier way.

\section{Introduction}

It is accepted that different abilities, interests and skills of individuals are unique to them, as each individual has their own physical development. With the innovations brought by the age we live in, the education and training opportunities provided for individuals with normal development characteristics as well as individuals with different developmental characteristics from their peers are gradually increasing. Students who cannot benefit from normal education

\footnotetext{
*Correspondency: ishakkozikoglu@yyu.edu.tr
} 
opportunities due to their differing developmental characteristics are named as special needs students (Aral \& Gürsoy, 2009). Education of disabled and non-disabled students together is called inclusive education. In inclusive education, the individuals with special needs will be together with the individuals with normal development, so the sense of dependence will decrease and they will be self-confident. At the same time, the life of the individuals with special needs in the society will be facilitated (Ministry of National Education [MoNE], 2010).

Special education services in Turkey date back to the 1950s. The execution process of special education services was transferred from the Ministry of Health and Social Assistance to the Ministry of National Education, which was the most important development of the period (Özyürek, 2009). Gazi Education Institute was established in 1952 in order to train personnel for special education services, served for two terms and then was closed in 1955 (State Planning Organization [SPO], 1992). The Psychological Service Center was established in 1955 in order to carry out the special education services in all our provinces in integrity, and the foundation of today's Guidance and Research Centers was formed. With the establishment of the Psychological Service Center, special classes were opened for mentally disabled students, and the first application examples of sub-special class practice took place later (Özsoy, 1990). The measures to be taken by the state were decided in 1956 with the law numbered 6660 in raising gifted and gifted children. The 1960s are important in order to regulate special education services legally and to train staff in universities in this field (Kargin, 2007).

With the implementation of the "Special Education Teaching Certificate Program" in 1978, classroom teachers and teachers working in different branches were certified in order to train teachers for all branches of special education (Akçamete \& Kaner, 1999). With the incorporation of special education services within General Directorate of Primary Education into the General Directorate in 1980, the planning and execution of special education services throughout the country took a systematic route (Şahin, 2003). Law numbered 2916, which entered into force in 1983, paved the way for children with special needs to receive inclusive education for the first time (MoNE, 2000). With the Decree Law numbered 573 which was adopted in 1997 and the Regulation on Special Education Services, which entered into force in 2000, it was discussed in detail how students with special needs should be evaluated and how appropriate educational environments, placement and individual education programs should be organized in this sense (Kargin, 2007).

How the placement process of individuals with special needs should be in the educational evaluation processes was discussed in the Special Education Services Regulation issued in 2006. Unlike the regulations that came into force in 1997 and 2000, it was stated in the 2006 Special Services Regulation that an "Education Plan" should be prepared for each individual who needs special education. It was explained in detail in the regulation that the training plans to be prepared and the goals that individuals with special needs will have to reach during the year should be determined in the Guidance Research Centers (called as RAM) by the assessment team, and prepared by the IEP team formed in the school or institution where the IEP is taught, Again, with this regulation, the educational evaluation process was defined legally and the steps to be followed in this process were expressed (Kargin, 2007).

The combination of an education program, individualization and planning elements constitute individualized education programs. With IEP, it is aimed to prepare an environment for individuals with special needs to receive educational support with their peers of normal development (Özyürek, 2009). IEP is defined as a special education program prepared by taking into account the needs of the individual, teacher and family for individuals who need special 
education. With this program, it is aimed that the individual in need of special education can benefit from the appropriate learning environments (special education classes, the school itself, and others.) and support units (therapy, rehabilitation, and alike). In this process, students who need special education or show different characteristics from their friends are determined by the classroom teacher. After the situation of the student is evaluated together with the school administration, the counselor, the classroom teacher and parents, an individualized education program is prepared for the relevant student (MoNE, 2010).

Individualized education programs (IEPs) constitute fundamental mechanisms to make special education services child-specific and improve the developmental outcomes of children with disabilities (Boavida et al., 2010). It is argued that IEP has become an instructive mechanism as well as an evaluative one. It functions as a method for assessing children's progress by encouraging parental involvement in setting and monitoring educational goals (Goodman \& Bond, 1993). The IEP is critical for educators, parents, and students. Through the IEP process, school-based teams (a) assess a student's educational needs, (b) develop meaningful and measurable goals for the student, (c) develop and implement a program of special education and related services (d) monitor student progress toward goals (Christle \& Yell, 2010).

IEP includes the current educational situation of the student, the long-term goals envisaged to be acquired by the student in an academic term, the short-term goals to be used to reach the long term, the materials and methods-techniques used to achieve these goals. In addition, it includes the time interval to reach the short-term goals, the monitoring/evaluation performed to determine whether the goals are achieved, and where, when or by whom the services will be provided to the student (Strickland \& Turnbull, 1990). In order for both the preparation and implementation of the IEP to be efficient, the IEP preparation committee consisting of the school principal and assistant, counselor, classroom teacher, branch teachers and parents should be in cooperation with each other (MoNE, 2018).

In order to determine the individual who needs IEP, the first thing to do is to create an informal process by using evaluation tools such as observations, interviews, checklists, and so on. In this process, the classroom teacher and the counselor should cooperate and prevent unnecessary evaluation of the student who does not have special needs and take the student into detailed evaluation (Kirk, Gallagher, Anastasiow, \& Coleman, 2006). If the student is below the grade level both academically and socially in this informal evaluation process, a detailed evaluation should be made. In detailed evaluation, a formal evaluation process is initiated by applying intelligence tests, which are widely used in Turkey. These formal evaluation results are supported with informal evaluation results and it is decided whether the individual is suitable for special education services (Kargin, 2007).

The most effective agent that actively takes part in the development, implementation and evaluation of IEP and determines at what level the needs of the student should be met is the teacher (Arivett, Rust, Brissie, \& Dansby, 2007). The person who communicates with the student, designs and implements the education program, uses the necessary material during the application and makes the evaluation is again the teacher. Therefore, teachers have a very important role in determining and evaluating what behaviors students can demonstrate (Gözütok, 1991).

When the literature is examined; Saraç and Çolak (2012) concluded that the physical characteristics of the classroom were insufficient in inclusive practices, the school personnel were insufficient in solving the problems of classroom teachers, and the assistance provided 
was dysfunctional and insufficient. Çuhadar (2006) reached the conclusion that although classroom teachers and school administrators think that IEP is compulsory and educationally essential, they continue their education and training based on trial and error without preparing IEP for inclusive students. Öztürk (2009) concluded that classroom teachers think that IEP is essential and beneficial for all stakeholders, teachers benefit from many resources in the process of preparing IEP, but the physical conditions of the school are not sufficient in the IEP application. Küçüker, Kargın and Akçamete (2002), in their study examining the views of the staff in RAM on the issues of IEP preparation, application, evaluation and family education, concluded that in-service training positively affected the issues of IEP preparation, monitoring and evaluation. In addition, a limited number of studies have been reached in the literature that examine teachers' attitudes towards IEP (Tike, 2007) and the challenges they experience (Noseless, 2019; Söğüt \& Deniz, 2018; Tike, 2007). Therefore, it can be said that there is a need for comprehensive studies to determine the attitudes and views of teachers, who have an active and important role in the IEP development, implementation and evaluation process, and the challenges they experience in this process.

The purpose of this study is to determine teachers' attitudes towards the IEP process and the challenges they experience in this process. For this purpose, the following research questions are addressed:

(1) What are the teachers' attitudes towards the IEP process and the challenges they experience during the IEP process?

(2) Is there a significant relationship between the teachers' attitudes towards the IEP process and the challenges they experience during the IEP process?

(3) Do teachers' attitudes towards the IEP process significantly predict the challenges they experience during the IEP process?

(4) What are the teachers' views concerning the IEP process?

It is thought that in IEP, which is created by the participation of teachers, school principals, target experts and families in order to organize, implement and evaluate the educational activities of students with special needs, determining the challenges that teachers experience in both development, application and evaluation process will contribute to the development of education programs prepared for these students. IEP is carried out in order to set appropriate goals at school to ensure the success of children with disabilities. The results revealed that IEP goals focus on three main issues: 1) improving school readiness, 2) improving communication (both sign communication and speech communication) and 3) improving pre-academic performance in targeted areas (Musyoka \& Clark, 2017). Research on IEP examines current practices and provides information on whether practitioners are implementing policies and if the effectiveness of current practice in providing meaningful educational benefit to students. Unfortunately,studies on IEP lack revealing the relationship between the quality of IEP and the education level of students. Current research on IEP shows that progress has been made in terms of student development, but we still have a long way to determine whether IEP is actually appropriate (Christle \& Yell, 2010).

As affective factors are a driving force of learning (Kasap \& Peterson, 2018; Kasap, 2021), in order for the IEP process to be effective, teachers should have a positive attitude towards this application. Therefore, it is important to determine the attitudes of teachers towards the IEP process, who have a critical role in the IEP process. In addition, the literature includes a limited number of studies on IEP. There is a need for up-to-date studies examining teachers' attitudes, views and problems about IEP. In this case, it is thought that this study will contribute to the 
literature in terms of both determining the teachers' attitudes, views and problems about IEP and providing in-depth data on the subject with the mixed method. In addition, this study is important in terms of determining the relationship and predictive power between teachers' attitudes towards IEP and the challenges they experience in the IEP process.

\section{Method}

\section{Research design}

In this study, explanatory sequential design, one of the mixed method designs, was used. In explanatory sequential design, firstly data are collected by quantitative methods, then qualitative data are collected based on the analysis of these data. In this design, quantitative and qualitative data are integrated and interpreted together (Creswell, 2014). First, quantitative data were collected in this study, and then qualitative data were collected and it was aimed to reach valid research results with comprehensive and supportive data. While determining the teachers to be interviewed in this study, diversity was provided by taking into account the variables of teachers' gender, branch, whether they received in-service training related to IEP and their inclusive education experiences.

In this study, a mixed method was used to evaluate teachers' attitudes towards the process of preparing individualized education programs and the challenges they experience from a deep perspective. The research design is presented in Figure 1.

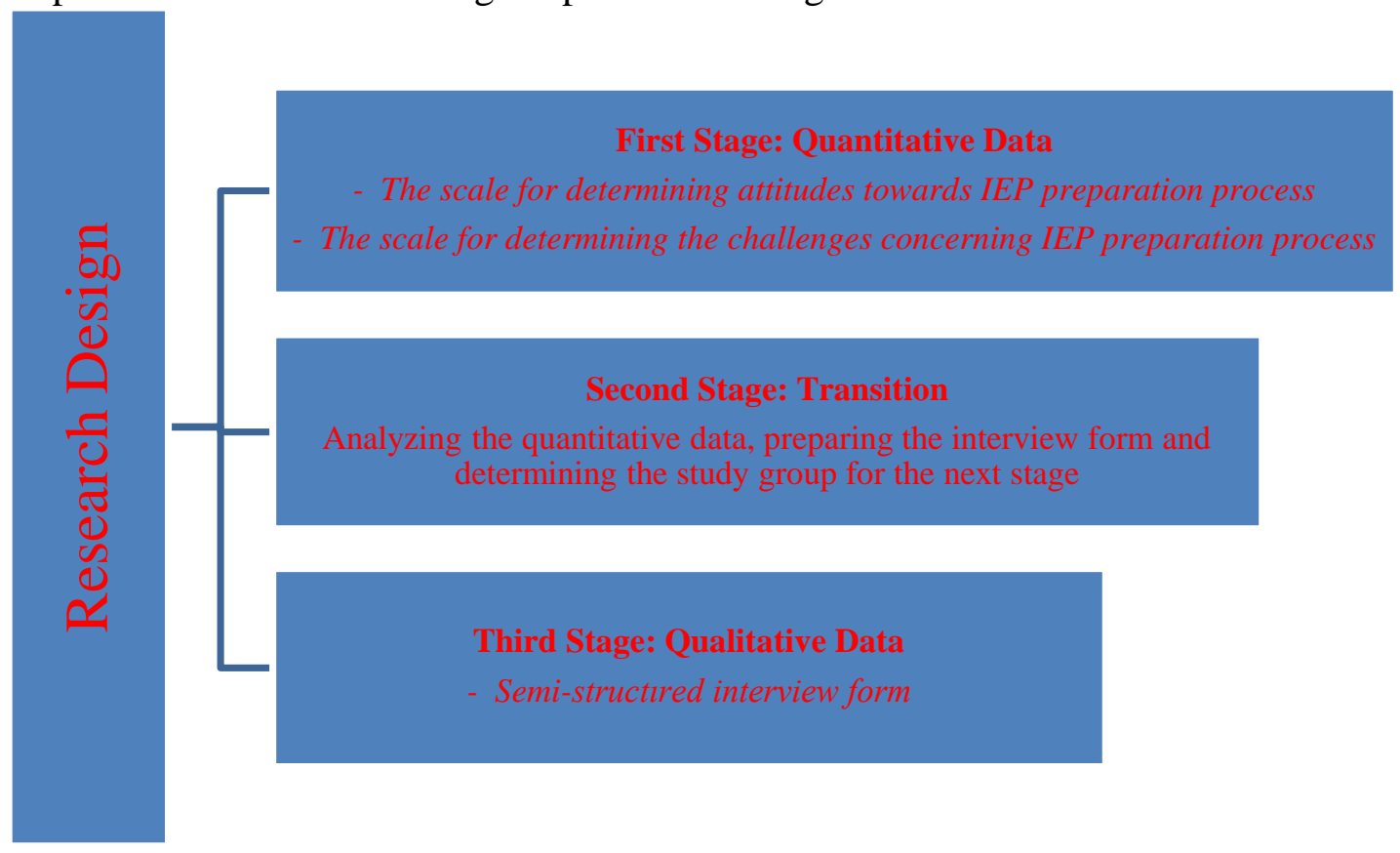

Figure 1. Research design

\section{Study group}

The study group of this study consists of 100 teachers working in the central districts of Van (İpekyolu, Edremit, Tusba) within 2019-2020 academic year. Criterion and convenience sampling methods were used in determining the study group. Certain criteria are determined in criterion sampling and individuals who meet the criteria are included in the study group (Yıldırım \& Şimşek, 2016). In convenience sampling method, the participants are selected from the ones who are easy to contact or to reach (Büyüköztürk et al., 2015). Easy accessibility and 
volunteerism were taken into consideration while determining the study group in the study, and the criteria for teachers was determined as having worked with students of IEP for at least one year. The distribution of teachers in the study group concerning their personal characteristics is presented in Table 1.

Table 1. Distribution of teachers by demographic characteristics

\begin{tabular}{llll}
\hline Variable & Category & Number & Percentage (\%) \\
\hline Gender & Female & 66 & 66.0 \\
& Male & 34 & 34.0 \\
\hline Branch & Classroom teacher & 60 & 60.0 \\
& Branch teacher & 40 & 40.0
\end{tabular}

As seen in Table 1, 66 of the teachers participating in the study are female and 34 of them are male. Sixty of the teachers are classroom teachers and 40 are working in other branches. In this study, face-to-face interviews were conducted with 15 teachers among the teachers who responded to the scale in order to provide qualitative data. The maximum variation sampling method, one of the purposeful sampling methods, was used in determining the teachers to be interviewed. Maximum variation sampling is used to reveal the different dimensions of the problem according to diversity (Yıldırım \& Şimşek, 2016). Ten of the teachers interviewed are female and five are male. Ten of them are classroom teachers and five are branch teachers. Seven of them received in-service training on IEP, and eight of them did not receive in-service training on IEP. All of the teachers had previous inclusive education experience.

\section{Data Collection Tools}

The scale for determining attitudes towards IEP preparation process

The scale developed by Tike (2007) consists of 15 items and three sub-dimensions: "IEP Perception", "Elements of IEP", "IEP Task Perception". The scale consists of a 5-point scale ranging from "totally agree" to "strongly disagree". The scale includes such items as "IEP shows where and how to start education.", "I think I will be beneficial to the student by participating in the IEP preparation process.". As a result of the test-retest for the scale, the reliability coefficient was calculated as 0.78 for the first sub-dimension, 0.76 for the second subdimension, 0.82 for the third sub-dimension and 0.81 for the total of the scale. In this study, Cronbach Alpha internal consistency coefficients of the scale were calculated as $0.81,0.75$, $0.72,0.86$, respectively. These values show that the data obtained from the scale are reliable.

\section{The scale for determining the challenges concerning IEP preparation process}

The scale developed by Tike (2007) has 20 items and four sub-dimensions: "Knowledge Level", "Challenges Concerning the IEP Process", "Challenges Concerning the IEP Team", "Challenges Concerning Sharing the IEP Responsibilities". The scale consists of a 5-point scale ranging from "totally agree" to "strongly disagree". The scale includes such items as "It would be very difficult to prepare IEP separately for each disabled student.", "I do not know what my responsibilities are concerning IEP.". As a result of the test-retest for the scale, the reliability coefficient was calculated as 0.78 for the first sub-dimension, 0.76 for the second subdimension, 0.82 for the third sub-dimension, 0.79 for the fourth sub-dimension. In this study, Cronbach Alpha internal consistency coefficients of the scale were calculated as $0.90,0.79$, $0.75,0.74$, respectively. These values show that the data obtained from the scale are reliable. 


\section{Semi-structured interview form}

The interview form developed by the researchers consists of four questions. In the interview form, there are questions about teachers' views (content, the need for the program, benefits) about IEP, their knowledge or deficiencies about IEP, challenges experienced in the implementation process of IEP and their suggestions for a healthier implementation of IEP. After the draft interview form was prepared, expert views were obtained from three academicians, namely Educational Sciences, Special Education and Turkish Education. In line with the views of the experts, some corrections were made in terms of content, language and clarity in the interview questions, and the interview form was finalized.

\section{Data analysis}

In this study, the mean and standard deviation values obtained from the scale were taken into account in order to determine teachers' attitudes towards the IEP preparation process and the challenges experienced in the IEP process. These values were interpreted between "1-1.79" as very low, "1.80-2.59" as low, "2.60-3.39" as moderate, "3.40-4.19" as high and "4.20-5.00" as very high level. Pearson Product Moments Correlation Coefficients were used to examine the relationship between the attitude towards the IEP preparation process and the challenges experienced in the IEP process. These values were interpreted between '0.00-0.29' as low level, '0.30-0.69' as moderate, '0.70-1.00' as high level. In addition, stepwise regression analysis was used to determine to what extent teachers' attitudes towards the IEP preparation process predicted the challenges they experienced in IEP process. Stepwise regression analysis is performed by including the independent variables that significantly affect the variance in the dependent variable in the order of importance (Büyüköztürk, 2018). Before the analysis, it was examined whether the assumptions were met or not. Accordingly, first of all, scatter graphics in sub-dimensions were examined and it was found that the linearity assumption was met. For multivariate normality, mahalonobis distance values were examined and extreme values were removed from the data set. By examining the relationships between the dependent variables for the multicollinearity problem, it was found that the highest relationship was "-.334". As a result, multivariate normality and linearity were provided, and it was concluded that there was no problem of multicollinearity between variables.

The descriptive analysis technique, which is a qualitative data analysis technique, was used in the analysis of the interview data. Descriptive analysis technique is the interpretation of qualitative data according to predetermined themes. Descriptive analysis consists of four stages that are creating a framework for descriptive analysis, processing data according to themes, defining and interpreting the findings (Yıldırım \& Şimşek, 2016). In this study, data were classified, described and interpreted by creating codes in the process of data analysis. The data were also supported by direct quotations in order to support the findings and present the teachers' views clearly. In order to ensure external reliability, detailed explanations about the position of the researcher and the participants were included in the study. The integrity and consistency of the data were reviewed to ensure internal validity, and detailed explanations regarding processes such as preparing the interview form, collecting and analyzing the data were included to ensure external validity. 


\section{Results}

Teachers' attitudes towards the IEP process and the challenges they experience during the IEP process

Concerning the first sub-question of the study, descriptive statistics of the scales and its sub-dimensions are presented in Table 2.

Table 2. Descriptive statistics of the attitude and challenges scales concerning the IEP process

\begin{tabular}{llcc}
\hline Scale & $\begin{array}{l}\text { Sub- } \\
\text { dimensions }\end{array}$ & $\bar{X}$ & ss \\
\hline Attitudes towards the IEP process (total) & & 3.54 & 0.55 \\
& IEP Perception & 3.74 & 0.62 \\
& Elements of IEP & 3.47 & 0.69 \\
Challenges experienced during the IEP process & IEP Task Perception & 3.31 & 0.69 \\
(total) & & 3.05 & 0.63 \\
\hline
\end{tabular}

As shown Table 2, it is seen that teachers' attitudes towards the IEP preparation process in total scale ( $\bar{X}=3.54$ ) and sub-dimensions of IEP perception ( $\bar{X}=3.74)$ and the elements of IEP ( $\bar{X}=3.47)$ are at high level, and their attitudes towards IEP task perception $(\bar{X}=3.31)$ was found to be at moderate level. In addition, it was revealed that the challenges that teachers experience during the IEP process $(\bar{X}=3.05)$ are generally at moderate level. The results concerning the challenges that teachers experience in IEP process are presented below, according to the sub-dimensions.

Descriptive statistics for the items in the "knowledge level" sub-dimension are presented in Table 3.

Table 3. Descriptive statistics for the "knowledge level" sub-dimension

\begin{tabular}{lcc}
\hline Knowledge Level & $\bar{S}$ & SS \\
\hline 1. I do not have enough information about IEP. & 2.94 & 1.09 \\
2. I do not have material support for learning IEP. & 3.38 & 1.12 \\
3. I do not know where to get support to learn about IEP. & 2.58 & 1.02 \\
4. I do not know what my responsibilities are concerning IEP. & 2.71 & 1.08 \\
5. I do not have the knowledge to determine the educational performance of the student. & 2.45 & 0.99 \\
6. I do not know how to determine annual goals during the preparation process of IEP. & 2.75 & 1.18 \\
7. I do not know with which activities and tools the IEP will be enriched. & 2.80 & 1.10 \\
Total & 2.80 & 0.82 \\
\hline
\end{tabular}

As shown in Table 3, it was found that teachers agreed on the item expressions related to the knowledge level concerning IEP process at a moderate level ( $\bar{X}=2.80$ ). It was found that they agree more on the items of "I do not have material support for learning IEP", "I do not have enough information about IEP." and "I do not know with which activities and tools the IEP will be enriched."

Descriptive statistics for the items in sub-dimension of "Challenges concerning the IEP process" are presented in Table 4. 
Table 4. Descriptive statistics for the items in sub-dimension of "challenges concerning the IEP process"

\begin{tabular}{lcc}
\hline Challenges concerning the IEP process & $\bar{X}$ & ss \\
\hline 1. I do not have any knowledge about the criteria to evaluate the student who has IEP. & 2.75 & 0.88 \\
2. It takes a long time to prepare IEP. & 2.73 & 1.05 \\
3. In implementing IEP, it is difficult to manage the curriculum of other students in the class. & 3.22 & 1.15 \\
4. The insufficiency of the class conditions makes it difficult to apply IEP. & 3.68 & 1.10 \\
5. It would be very difficult to prepare IEP separately for each disabled student. & 3.14 & 1.12 \\
6. Crowded classes make it difficult to prepare IEP. & 3.77 & 1.12 \\
7. It is difficult to explain the IEP to the parents of other students in the class. & 3.36 & 1.06 \\
Total & 3.24 & 0.71 \\
\hline
\end{tabular}

As shown in Table 4, it was found that teachers agreed on the item expressions in sub-dimension of "challenges concerning the IEP process" at a moderate level $(\bar{X}=3.24)$. It was found that they agree more (at a high level) on the items of "Crowded classes make it difficult to prepare IEP." and "The insufficiency of the class conditions makes it difficult to apply IEP." Descriptive statistics for the items in the sub-dimension of "Challenges Concerning the IEP Team" are presented in Table 5.

Table 5. Descriptive statistics for the items in the sub-dimension of "challenges concerning the IEP team"

\begin{tabular}{lll}
\hline Challenges Concerning the IEP Team & $\bar{X}$ & Ss \\
\hline 1. The school does not have a suitable room to hold the IEP team meetings. & 3.06 & 1.30 \\
2. Team members are reluctant to prepare IEP. & 3.10 & 1.12 \\
3. IEP team members do not attend the meetings regularly. & 2.88 & 1.00 \\
Total & 3.02 & 0.94 \\
\hline
\end{tabular}

As shown in Table 5, it was found that teachers agreed on the item expressions in sub-dimension of "challenges concerning the IEP team" at a moderate level $(\bar{X}=3.02)$. It was found that they agree more on the items of "There is no suitable room in the school to hold the IEP team meetings." and "Team members are reluctant to prepare IEP." Descriptive statistics for the items in the sub-dimension of "Challenges Concerning Sharing the IEP Responsibilities" are presented in Table 6 .

Table 6. Descriptive statistics for the items in the sub-dimension of "challenges concerning sharing the IEP responsibilities"

\begin{tabular}{lcc}
\hline Challenges Concerning Sharing the IEP Responsibilities & $\bar{X}$ & Ss \\
\hline 1. The school administration does not help enough about IEP. & 3.00 & 1.07 \\
2. I am always held responsible when it comes to the education of disabled students and IEP. & 2.55 & 1.14 \\
3. Families expect a lot from the teacher about the education of disabled students. & 3.94 & 0.89 \\
Total & 3.16 & 0.70 \\
\hline
\end{tabular}

As shown in Table 6, it was found that teachers agreed on the item expressions in sub-dimension of "challenges concerning sharing the IEP responsibilities" at a moderate level ( $\bar{X}=3.16$ ). It was found that they agree more to the items of "Families expect a lot from the teacher about the education of disabled students." and "The school administration does not help enough with IEP." 


\section{The relationship between the teachers' attitudes towards the IEP process and the challenges they experience during the IEP process}

Concerning the second sub-question of the study, Pearson Product Moments Correlation Coefficient values are presented in Table 7.

Table 7. Pearson product moments correlation coefficients of the research dependent variables

\begin{tabular}{llllll}
\hline Variables & $\begin{array}{l}\text { Challenges in } \\
\text { IEP (total) }\end{array}$ & $\begin{array}{l}\text { Knowledge } \\
\text { Level }\end{array}$ & $\begin{array}{l}\text { Challenges } \\
\text { Concerning the } \\
\text { IEP Process }\end{array}$ & $\begin{array}{l}\text { Challenges } \\
\text { Concerning } \\
\text { the IEP Team }\end{array}$ & $\begin{array}{l}\text { Challenges } \\
\text { Concerning Sharing } \\
\text { the IEP } \\
\text { Responsibilities }\end{array}$ \\
\hline $\begin{array}{l}\text { Attitude towards } \\
\text { IEP (total) }\end{array}$ & $-.334^{* *}$ & $-.212^{*}$ & $-.327^{*}$ & $-.266^{* *}$ & $-.254^{* *}$ \\
\hline$p<.01^{* *}$ & & & &
\end{tabular}

As shown in Table 7, a moderate level, negative and significant relationship was found between teachers' attitudes towards IEP and total scale of the challenges they experience in IEP process $(\mathrm{r}=-.334 ; \mathrm{p}<.01)$, sub-dimension of the challenges concerning the IEP process $(\mathrm{r}=-.327 ; \mathrm{p}$ $<.01)$ ); while a low level, negative and significant relationship was found between teachers' attitudes towards IEP and knowledge level $(\mathrm{r}=-.212 ; \mathrm{p}<.01)$, challenges concerning the IEP team $(r=-.266 ; p<.01)$, challenges concerning sharing the IEP responsibilities $(r=-.254 ; p$ $<.01)$ sub-dimensions.

\section{Whether attitudes towards the IEP process significantly predict the challenges experienced during the IEP process}

The stepwise regression analysis results concerning the third sub-question of the study are presented in Table 8.

Table 8. Stepwise regression analysis results concerning the challenges teachers experience in IEP process

\begin{tabular}{lllll}
\hline Steps & Predictive Variables & $\boldsymbol{B}$ & $\begin{array}{l}\text { Prediction Power } \\
(\boldsymbol{R})\end{array}$ & $\begin{array}{l}\text { Explained } \\
\text { Variance }\left(\boldsymbol{R}^{2}\right)\end{array}$ \\
\hline 1. & IEP Task Perception & -.453 & .205 & .197 \\
\hline
\end{tabular}

As shown in Table 8, the "IEP task perception" sub-dimension of the attitude scale concerning the IEP process explains $19.7 \%$ of the variance in the challenges teachers experience in the IEP process. ANOVA results for stepwise regression analysis given in Table 8 are presented in Table 9.

Table 9. ANOVA results on predicting the challenges teachers experience in IEP process

\begin{tabular}{llllll}
\hline Model & Sum of squares & Sd & Mean of squares & $\boldsymbol{F}$ & $\boldsymbol{p}$ \\
\hline Regression & 8.106 & 1 & 8.106 & \multirow{2}{*}{24.980} & .000 \\
Residual & 31.477 & 97 & .325 & & \\
\hline
\end{tabular}

As shown in Table 9, the predictive power calculated in the stepwise regression analysis in Table 8 is significant $(F(1,97)=24.980, p<.000)$. Regression analysis concerning the challenges teachers experience in IEP process was carried out in one step and one variable was found to be a significant predictor. However, it was found that the variables "IEP Perception" and "Elements of IEP", which are sub-dimensions of the attitude scale towards IEP, do not contribute significantly to the total variance. 


\section{Teachers' views concerning the IEP process}

Concerning the fourth sub-question of the study, qualitative results were examined under four themes that are "Views on IEP implementation", "Teacher competencies concerning IEP", "Challenges that teachers experience in IEP implementation process" and "Suggestions about IEP".

\section{Views on IEP implementation}

Concerning this theme, teachers were asked "What do you think about Individualized Education Programs (IEP)?". When the views of the teachers on this subject are examined, it is seen that all the teachers expressed a positive view. While all the teachers $(n=15)$ found the IEP application useful, almost all $(n=13)$ emphasized that IEP is an essential application. The teachers' prominent views concerning this situation are presented below.
"IEP is a support program prepared for students who need special education. Students may be gifted, have a different need, or have learning difficulties. I think IEP is essential in order to organize these and to be carried out in a certain order. I think we can see its benefits within this framework." (T4)
"I think IEP is absolutely beneficial, I see the required progress in the student if it is really implemented in a planned and regular manner." (T6)

As stated in the teachers' views above, teachers stated that IEP was prepared for individuals who need special education, it is very efficient when applied within a certain order and plan, and they can see its benefits in this direction. In addition, some teachers stated that IEP is a useful application to bring students who fall behind academically to a better point $(n=6)$ and students with special needs can gain social skills thanks to IEP $(n=6)$. The striking views of the teachers on these situations are given below.
"I think IEP is very efficient for a child with special needs if it is applied correctly, it enables that child to socialize without being discriminated/isolated, so I think it is useful." (T8) "I think IEP is essential and useful for the children with disabilities to be together with children with normal development, to help the disabled child reach the academic level expected from him and at the same time to help the child socialize." (T10)
"I think IEP is very useful in helping students with special needs socialize together with other friends and reach a certain level." (T13)

As stated in the teachers' views above, IEP helps children with special needs gain social skills and reach better academic positions. In addition, some teachers stated that IEP helps to know students with special needs better $(n=3)$ and provides students with basic skills $(n=2)$. The teachers' prominent views are presented below.

"We can fully see children with special needs thanks to IEP. We can see the behaviors the child can or cannot demonstrate. If we know the child and act accordingly, I really think that efficiency will be obtained." (T7)

"I find IEP very useful for students with special needs both in providing basic skills and social skills." (T5)

\section{Teacher competencies concerning IEP}

Concerning this theme, teachers were asked "Do you think you have enough information about IEP? On which aspects do you think you have deficiencies?" was posed to 
the teachers. Almost all of the teachers $(n=12)$ stated that they had deficiencies about IEP, while three teachers stated that they had sufficient knowledge. The teachers' prominent views are presented below.

"I think I do not have enough information about IEP, I act according to the current process of the lesson in the field of application. In the application, I give what the child can receive at that moment. When I am to make a plan ahead of time, I don't want to do it because I feel incomplete." (T5)

"I think I have a lot of deficiencies in the planning, implementation and assessment and evaluation areas of IEP." (T3)

As stated in the teachers' views above, the teachers stated that they do not have enough information about IEP. In IEP process, teachers stated that they have deficiencies in measurement and evaluation $(n=9)$, implementation $(n=5)$ and planning $(n=3)$, respectively. The striking views of the teachers on this situation are given below.

"I don't think I have enough information about IEP. Since I do not have any knowledge in planning, implementation or evaluation, I do not know what to provide the student with and how to get feedback." (T9)

"Although I have a certificate in this field, I think I have a deficiency, I also do research to make up for my deficiency, but I often see that I cannot get feedback from students in the field of assessment and evaluation." (T12)

"I think I do not have enough information; our guidance counselor sometimes helps in this subject. I deal with the child individually in the field of planning and implementation, but I don't know what to do in the field of assessment and evaluation." (T14)

"I think I do not have the necessary knowledge about IEP. I have difficulties mostly in implementation and assessment/evaluation." (T15)

As stated in teachers' views above, it is seen that besides the teachers generally do not have sufficient knowledge about IEP planning, implementation and assessment/evaluation processes, they stated that they had difficulties and did not know what to do, especially because they had critical deficiencies in IEP process.

\section{Challenges that teachers experience in IEP implementation process}

Concerning this theme, the teachers were asked "What are the challenges you experience in the IEP implementation process?" What do you think about the factors that cause these challenges?" Almost all of the teachers $(n=11)$ stated that they had difficulties in the planning and implementation process of IEP. Teachers stated the reasons for their having difficulties as not having enough knowledge $(n=4)$, not receiving any support from the family/family's not accepting $(n=4)$, inadequacy of physical conditions and materials $(n=4)$, crowded classes $(n=3)$, classroom teachers' not having knowledge about IEP $(n=2)$, respectively. The striking views of the teachers on this situation are presented below.

\footnotetext{
"Because the classes are crowded, there is insufficient material available and I cannot get the required support from the family, I have difficulties in both planning and implementation." (T3)

"Since I do not have enough information about IEP, I have problems in both planning and implementation." (T8)

"While applying IEP, I definitely have difficulties due to the physical conditions of the school, I also have difficulties because there is no essential material." (T10)
} 
"I mostly have problems with IEP implementation. I have difficulties because the class is crowded, due to the physical conditions of the school and as the classrooms are not sufficient, and since parents often do not accept the special situation of their child." (T11)

In addition, some teachers $(n=4)$ stated that they had difficulties in the field of assessment and evaluation during IEP process, one teacher could not communicate because the family did not speak Turkish, and one teacher stated that the child with special needs had difficulty in communication due to speech difficulties. Some of the teachers' views are given below.

"It is difficult for the student to adapt to the class and then to me, there is a speech problem. Since some of the families did not speak Turkish, we had difficulties in understanding in every field." (T2)

"While I do not have any difficulties in planning and implementing the IEP, I have difficulties in evaluating the information I provide." (T6)

"While I have difficulty in getting down to the level of the student and getting their attention while applying IEP; since my deficiency is in the field of measurement and evaluation, I have more problems in measurement and evaluation." (T13)

\section{Suggestions about IEP}

Concerning this theme, the teachers were asked "What are your suggestions for a healthier execution of IEP? What do you think should be done?". Most of the teachers $(n=11)$ emphasized that classroom teachers should be informed about special education through seminars or in-service training. In addition, some teachers made suggestions such as physical conditions should be improved and material support should be provided $(n=4)$, parents should be educated about special education $(n=2)$. The highlights of the teacher suggestions are given below.

\footnotetext{
"Rather than receiving an ostensible in-service training for classroom teachers, if necessary, a serious in-service training should be given during the seminar periods, and special education services should be given to us in a more comprehensive way." (T7)

"In order for the student to be diagnosed correctly and especially to make the diagnosis early, trainings can be given to parents to have information in this sense, we (classroom teachers) should definitely be given serious in-service training, and the physical conditions of the schools should be improved for the student who will receive inclusive education." (T10)

"Teachers should definitely be included in in-service training, and teachers who have inclusive students should be taken into in-service training, inspected and evaluated at intervals." (T13)
}

As seen above, teachers stated that especially classroom teachers should receive in-service training, families should be informed about special education and physical conditions should be improved in order to conduct IEP more properly. In addition, one of the teachers stated that there should be feasible programs in order to conduct IEP in a healthier way, the class size should be reduced and there should be cooperation between the family, classroom teachers and guidance counselor. Teacher suggestions are presented below.

"The family, classroom teacher and guidance counselor should be in constant cooperation." (T3)

"Applicable programs should be prepared, I think that our main purpose for the first four grades in general should be reading and writing." (T4) 
"If there are students as part of inclusive education in classrooms and if you want to be efficient, the class size should definitely be reduced, I think classroom teachers should receive serious in-service training." (T5)

\section{Discussion and Conclusion}

In this study, it was concluded that teachers' attitudes towards the IEP process are at a high level, in other words, teachers generally have positive views about the IEP process. These results correspond to the interview data. In the interviews with the teachers, it was found that according to teachers IEP application improves the development of both academic and social skills of children with special needs. It was concluded that all of the teachers found the IEP application useful and almost all of them thought IEP is an essential application. In parallel with the results of this study, Öztürk (2009) found that classroom teachers seem IEP as essential, and IEP is beneficial for both the family and the teacher. Similarly, in the study of Öztürk and Eratay (2010), five of the teachers reached the conclusion that IEP is essential, and four teachers stated that IEP is beneficial for both students and families. In this case, it can be said that teachers have a positive attitude towards the IEP process. As emphasized by the teachers on this result, it can be thought that IEP application positively improves the development of both academic and social skills of children with special needs. Based on these results, it is possible to say that IEP application is a useful application in meeting both the educational and social needs of students with special needs.

This study concluded that the challenges teachers experience during IEP process are generally at a moderate level. Similarly, in the interviews with teachers, almost all of the teachers stated that they had difficulties in planning and implementation process of IEP. In parallel with the results of this study, Çuhadar (2006) and Kuyumcu (2011) concluded in their studies that teachers had difficulties in working with students due to lack of knowledge in the preparation and development phase of IEPs and due to the incomplete application of the developed IEPs. Therefore, it can be said that teachers have difficulties in planning and implementing IEP.

It was concluded that teachers agree with the statements in the "knowledge level" at a moderate level which is one of the sub-dimensions of the scale about the challenges teachers experience in IEP process, The teachers stated that they do not have sufficient knowledge about IEP, and they do not know with which activities and tools the IEP will be enriched. Similarly, in the interviews with the teachers, it was concluded that the teachers did not have enough knowledge about IEP. It was found that besides the fact that the teachers did not have sufficient knowledge about IEP planning, implementation and assessment/evaluation processes in general, they stated that they had difficulties and did not know what to do especially because they had important deficiencies in IEP process concerning measurement and evaluation. These results support the results of similar studies in the literature. In parallel with the results of this study, Y1lmaz (2013) concluded that teachers did not have the required knowledge or skills concerning the IEP process. Similarly, Deniz (2018) concluded that teachers have difficulties in applying assessment and evaluation techniques for students with special needs. Based on the results of this research and similar studies in the literature, it is possible to say that the teachers do not have enough knowledge about IEP planning, implementation and assessment/evaluation processes. It is very important for teachers to have sufficient knowledge and equipment about the IEP process in order to develop, apply and evaluate IEP as desired. Therefore, it can be said that teachers who have an important role in the IEP team should have sufficient knowledge about IEP in order to carry out IEP in a healthier way, and there is a need for in-service training for teachers on this aspect. 
It was concluded that teachers agreed at a moderate level with the statements in the "challenges concerning IEP process", another sub-dimension of the scale related to challenges teachers experience in IEP process. Similarly, in the interviews with the teachers, it was found that teachers had difficulties in IEP process due to the inadequate physical conditions, material support and the crowded classroom. In parallel with the results of this study, several studies (Akkoyunluoğlu, 2019; Kuyumcu, 2011; Sanır, 2009) concluded that there is lack of materials used in the lessons and the physical infrastructure was insufficient during the IEP process. Therefore, it can be said that the physical conditions of the school/classroom and the lack of materials for IEP caused difficulties for teachers in the IEP process. Developing the training materials needed in the planning, implementation and evaluation of the IEP and providing the tools are important for the more efficient implementation of the IEP (MoNE, 2006). In this case, it is possible to say that both the classroom and the school should be arranged according to the needs of students with special needs in the IEP implementation process and the use of necessary materials in this process will create chances for a better implementation of IEP and positive changes on the student.

It was concluded that teachers agreed at a moderate level to the statements in "challenges concerning the IEP team" and "challenges concerning sharing the IEP responsibilities ", which are the other sub-dimensions of the scale related to the challenges teachers experience in IEP process. Teachers stated that the appropriate room to hold the IEP team meetings was not at the school, the team members were reluctant to prepare IEP, the families expected a lot from the teacher about the education of the disabled student and the school administration did not provide the adequate assistance in implementing IEP. Similarly, in the interviews with the teachers, it was concluded that teachers had difficulties in IEP process due to the family's not accepting the situation of the child in the preparation process of IEP, the classroom teacher's not having enough knowledge about IEP and the family's not being able to speak Turkish. Similarly, Ersan and Ata (2016) concluded in their study that there was no collaboration between teachers and the family during the implementation of IEP, there were no support rooms in the school, and parents were unconscious about this issue. Saraç and Çolak (2012) concluded that the classroom teachers could not get enough help from the staff in the school in solving the problems and the aids were not functional. Based on the results of this research and similar studies in the literature, it can be said that the lack of suitable rooms to hold IEP team meetings in schools during the IEP process and the lack of effective communication, sharing and cooperation between IEP stakeholders (teachers, families, IEP team members, school administrators) can cause difficulties for teachers in the IEP process. Individuals in the IEP team should have a high level of communication skills with each other. Each member in the team can bring important information that can help better planning, implementation and evaluation of IEP, and in this case, it can be very useful for individuals with special needs (Kargin, 2013). Therefore, it is thought that the communication and cooperation of the members of the IEP team will enable better planning, implementation and evaluation of the IEP.

This study concluded that there is a moderate, negative and significant relationship between the teachers' attitudes towards IEP and the challenges they experience in IEP process. Therefore, it can be said that as the positive attitudes of the teachers about IEP increases, the challenges they experience during IEP process decrease. In addition, it was concluded that "IEP task perception", which is one of the sub-dimension of the IEP attitude scale, explains about onefifth of the variance concerning the challenges they experience in IEP process. One of the most important factors in the success of the IEP implementation is the attitudes of the teachers towards the IEP preparation process. In this process, if the teacher is willing to prepare IEP and exhibits a positive attitude, the most important element for the successful implementation of 
IEP will be completed (Gürkan, 1991). In order for IEP to be successful, the teacher should know the student well, be aware of the needs of the student with special needs, know how much support can be received and from whom support should be received, and should show an accepting attitude to get support from other experts, if necessary, in communication with the family (Kircaali-Ifftar, 2004). Based on these results, it is possible to say that the teacher's having a positive and accepting attitude towards the student and IEP in the process of preparing IEP is very important for IEP to be successful.

\section{Suggestions}

In this study, teachers developed suggestions for classroom teachers to receive in-service training, inform families about special education, improve physical conditions, have applicable programs, reduce the class size and collaboration between the family, classroom teachers and guidance counselors is essential in order to conduct IEP in schools in a healthier way. The following suggestions are presented in this study in line with the teacher suggestions and the results obtained from this study.

- It may be suggested to provide teachers with practical in-service trainings concerning the IEP planning, implementation and evaluation process, and to inform teachers about their responsibilities in the process.

- Trainings can be organized for parents about what the individualized education program is, how they can contribute to this program and what its benefits will be particularly for the child.

- In order for the individualized education program to be more useful, the necessary physical conditions in schools and classrooms can be arranged according to students with special needs and essential materials can be provided within the program.

- It may be suggested to establish IEP support rooms and organize various activities in schools to ensure interaction and cooperation between stakeholders in the IEP team.

- This study is limited to the scale and interview form, and the teachers working in Van. In future studies, data can be obtained on IEP process with data collection tools such as observation and alike and different samples (school administrators, parents, and others) can be studied.

- Concerning the theoretical and practical implications for future research, curriculum development studies may be conducted for IEP based on need analysis of the challenges that teachers experience during IEP process. In order to determine the effectiveness of IEP program, curriculum evaluation studies may be conducted, as well.

\section{References}

Akçamete, G., \& Kaner S. (1999). Cumhuriyetin 75. yılında çocuğa yönelik özel eğitim çalışmaları [Special education activities for children in the 75th anniversary of the Republic]. 2nd National Child Culture Congress: Republic and Child, Ankara University Child Culture Research and Application Center Publications, Ankara.

Akkoyunluoğlu, Ö. (2019). Determination of music teachers' difficulties in preparing individualized training program and the investigation of their views about inclusive practices (Unpublished master thesis). Atatürk University, Institute of Educational Sciences: Erzurum.

Aral, N., \& Gürsoy, F. (2009). Özel ĕgitim gerektiren çocuklar ve özel eğitime giriş [Children requiring special education and introduction to special education]. İstanbul: Morpa Cultural Publications. 
Arivett, D. L., Rust, J. O., Brissie, J. S., \& Dansby, V. S. (2007). Special education teachers' perceptions of school psychologists in the context of individualized education program meetings. Education, 127(3), 378-388.

Boavida, T., Aguiar, C., McWilliam, R. A., \& Pimentel, J. S. (2010). Quality of individualized education program goals of preschoolers with disabilities. Infants \& Young Children, 23(3), 233-243.

Burunsuz, E. (2019). Teachers' opinions on the implementation of individualized education program for teachers in elementary education schools (Unpublished master thesis). Zonguldak Bülent Ecevit University, Institute of Social Sciences: Zonguldak.

Büyüköztürk, Ş., Akgün, Ö. E., Demirel, F., Karadeniz, Ş., \& Çakmak, E. K. (2015). Bilimsel araștırma yöntemleri [Scientific research methods]. Pegem Publications.

Christle, C. A., \& Yell, M. L. (2010). Individualized education programs: Legal requirements and research findings. Exceptionality, 18(3), 109-123.

Creswell, J. W. (2014). Research Design: Qualitative, quantitative and mixed methods approaches (4th ed.). Thousand Oaks, CA: Sage.

Ersan-Deniz, T., \& Ata, S. (2016). Preschool teachers' opinions/views on developing the individualized education program. Trakya University Journal of Education Faculty, Special Issue, 162-177.

Goodman, J. F., \& Bond, L. (1993). The individualized education program: A retrospective critique. The Journal of Special Education, 26(4), 408-422.

Gözütok, D. (1991). Evaluation of professional behaviours according to the perceptions of teachers and students. Ankara University Journal of Educational Sciences Faculty, 24(2), 405-409.

Gürkan, T. (1991). Pre-school education in Finland. Ankara University Journal of Educational Sciences Faculty, 24(2), 353-369.

Kargın, T. (2007). Eğitsel değerlendirme ve bireyselleştirilmiş eğitim programı hazırlama süreci [Educational evaluation and individualized education program preparation process]. Ankara University Special Education Journal of Educational Sciences Faculty, 8(1), 1-15.

Kasap, S. (2021). Attitude towards the first language and its effects on first language lexical attrition. International Journal of Kurdish Studies, 7(1), 65-81.

Kasap, S., \& Peterson, R. (2018). An interview on the role of input in second language learning. Learning Journal of Education and Practice, 9(13), 81-87.

Kırcaali-İftar, G. (2004). Baş makale: Özel eğitimde fokus grup araştırmaları [Editorial: Focus group research in special education]. Ankara University Special Education Journal of Educational Sciences Faculty, 5(1), 1- 7.

Kirk, A. S., \& Gallagher, J. J., Anastasiow, J. N., \& Coleman, R. M. (2006). Educating exceptional children (12th ed). Boston: Houghton Mifflin.

Kuyumcu, Z. (2011). Problems faced by teachers in the process of developing and implementing an individualized education plan (IEP) and suggestions for solutions to these problems (Unpublished master thesis). Ankara University, Institute of Educational Sciences: Ankara

Küçüker, S., Kargın, T., \& Akçamete, G. (2002). Improving the guidance and research centers personnels' opinions and perceptions of self-efficacy about the act of special education. Educational Sciences and Practice, 1,101-113.

MoNE (2000). Özel eğitim hizmetleri yönetmeliği [Special education services regulation]. Retrieved from: http://www.resmigazete.gov.tr/main.aspx?home= http://www.resmigazete.gov.tr/arsiv/23937_1.pdf\&main=http://www.resmigazete.gov.tr/a rsiv/23937_1.pdf.

MoNE (2006). Özel ĕgitim hizmetleri yönetmeliği [Special education services regulation]. Retrieved from: https://www.resmigazete.gov.tr/eskiler/ 2006/05/20060531-2.htm.

MoNE (2010). Okullarımızda 3n/lk (neden, nasıl, niçin, kaynaştırma) [3n/lk in our schools (why, how, why, inclusive)]. General Directorate of Special Education Guidance and Counseling Services, Ankara. 
MoNE (2018). Özel ĕgitim hizmetleri yönetmeliği [Special education services regulation]. Retrieved from: https://www.resmigazete.gov.tr/eskiler/ 2018/07/20180707-8.htm.

Musyoka, M. M., \& Clark, M. D. (2017). Teachers' perceptions of individualized education program (IEP) goals and related services. Journal of Developmental and Physical Disabilities, 29(1), 5-23.

Özsoy, Y. (1990). Special education in Turkey. Educational Sciences I. National Congress, Ankara University Faculty of Educational Sciences Publications, Ankara.

Öztürk, C. (2009). Determining the opinions of the teachers of mentally retarded students who attend the education application school about the individualized education program (Unpublished master thesis). Abant İzzet Baysal University, Institute of Social Sciences: Bolu.

Öztürk, C. Ç., \& Eratay, E. (2010). Determining opinions of teachers of students with mental retardation attending an education application school on the individualized education program. Journal of Abant İzet Baysal University, 10(2), 146-159.

Özyürek, M. (2009). Bireyselleştirilmiş eğitim programı temelleri ve geliştirilmesi [Individualized education program basics and development]. Ankara: Kök Publications.

Sanir, H. (2009). Evaluation of the problems of the students who are in inclusive education in academic learning according to teacher and family opinions (Unpublished master thesis). Selçuk University, Institute of Social Sciences: Konya.

Saraç, T., \& Çolak, A. (2012). Elementary school teachers' views and suggestions regarding the problems encountered in the process of inclusive applications. Mersin University Journal of Education Faculty, 8(1), 13-28.

Sögüt, D. A., \& Deniz, S. (2018). Rigours which class teachers encounter with preparing individualized education program (IEP) and assessment of views related to inclusive practices. Erzincan Journal of Education Faculty, 2(20), 423-443.

State Planning Organization [SPO]. (1992). State planning agency report. State Planning Agency, Ankara.

Strickland, B. B., \& Turnbull, A. P. (1990). Developing and implementing individualized education programs. Columbus $\mathrm{OH}$ : Merrill.

Şahin, S. (2003). Özel eğitim tarihçesi [History of special education]. A. Ataman (Ed.). In Özel gereksinimli çocuklar ve özel eğitime giriş [Children with special needs and introduction to special education]. Gündüz Education and Publications: Ankara.

Tike-Bafra, L. (2007). Sınıf öğretmenleri, rehber ögretmenler ve RAM çalışanlarının bireyselleştirilmiş eğitim programlart hazırlama sürecine ilişkin tutumlart ve karşılaşılabilecek güçlüklerin belirlenmesi [Determining the attitudes of classroom teachers, counselors and RAM staff towards the process of preparing individualized education programs and the difficulties that may be encountered] (Unpublished master thesis). Ankara University, Institute of Educational Sciences: Ankara.

Yıldırım, A., \& Şimşek, H. (2016). Sosyal bilimlerde nitel araştırma yöntemleri [Qualitative research methods in social sciences]. Ankara: Seçkin Publications.

Y1lmaz, M. F. (2013). Investigation of the challenges primary school administrators face in the application of individualized education programs (IEP) (the case of the central districts of Gaziantep province) (Unpublished master thesis). Hasan Kalyoncu University, Institute of Social Sciences: Gaziantep. 